\title{
Nurse practitioners' attitudes to nutritional challenges dealing with the patients' nutritional needs and ability to care for themselves in a fast track program
}

\author{
J ytte Graarup ${ }^{1}$, Preben Ulrich Pedersen², Merete Bjerrum ${ }^{3}$ \\ 1. Copenhagen University Hospital, Rigshospitalet, the Heart Center, Blegdamsvej, Copenhagen, Denmark. 2. Center for \\ Clinical Guidelines, Department of Health Science and Technology, Aalborg University, Aalborg, Denmark. 3. School of \\ Public Health, Department of Nursing Science, Aarhus University, Aarhus, Denmark.
}

Correspondence: Jytte Graarup. Address: Soehaven 26, 3500 Vaerloese, Denmark. Email: jytte.graarup@regionh.dk

Received: November 27, 2013 Accepted: March 3, $2014 \quad$ Online Published: March 26, 2014

DOI : 10.5430/jnep.v4n5p136 URL: http://dx.doi.org/10.5430/jnep.v4n5p136

\section{Abstract}

Background: Nutrition plays an important role to the success of fast track programs, but under nutrition are still reported. Nutritional care seems to be a low priority among nurses even though it is well-known that insufficient nutrition has severe consequences for the patients. The aim is to report to what extent a training program has made Nutritional Nurse Practitioners aware of the nutritional care for short-term hospitalized patients, and how they deal with patients' nutritional needs and ability to provide self-care in the context of a fast track program.

Methods: Deductive content analysis was used to analyse data from four focus group interviews. Sixteen Nutritional Nurse Practitioners from either medical or surgery wards participated. The Nutritional Nurse Practitioners were interviewed twice. The interviews were recorded and verbally transcribed.

Results: In the Nutritional Nurse Practitioners' opinion nutritional care is as important as any other treatment. Nutritional care should be planned with the patients to stimulate the patient to be active during admission and after discharges. Therefore, information and guidance to the patients and their relatives about nutrition is essential. It seems to be difficult for the Nutritional Nurse Practitioners to focus on nutritional care when it comes to everyday. Firstly due to time constraints and secondly higher priority is given to tasks delegated by the physician.

Conclusions: Despite Nutritional Nurse Practitioners are responsible for nutritional care and possess knowledge and skills to care for patients at nutritional risk, they find it challenging to handle nutritional problems. They do not explicitly pay attention to patients on fast track programs, but give higher priority to tasks delegated by the physician. This priority and the fact that Nutritional Nurse Practitioners find it difficult to exemplify evidence-based nursing interventions for specific nutritional problems, makes the nursing profession imperceptible to patients, relatives and healthcare professionals as a resource within its own area of responsibility.

\section{Key words}

Attitude, Awareness, Deductive content analyses, Fast track program, Nutrition, Nutritional care, Nutritional guidelines, Nutritional nurse practitioners, Selfcare, Shared responsibility 


\section{I ntroduction}

The development of fast track programs (FTPs) is widespread and increased. The programs are intended to accelerate postoperative recovery, to reduce the complication rate and lead to a more appropriate use of hospital resources and health care services ${ }^{[1-3]}$.

FTP is an interdisciplinary, evidence-based, multimodal regime based on aims of shared responsibility and standards for patient treatment and care. Furthermore, an interdisciplinary teamwork between health professionals and patients is a required precondition for the success of FTPs ${ }^{[4,5]}$.

FTP has maximum involvement of patients and optimises focus on pain relief, immediate mobilisation, and sufficient nutrition ${ }^{[5-7]}$. Nurses play an important role in the success of FTPs ${ }^{[5]}$, as they are responsible for developing and managing evidence-based standards for care ${ }^{[4,5]}$. Care plans must combine the aims behind the programs and take the individual patient's perspective into account ${ }^{[8]}$. To be an equal part of the multidisciplinary team, nursing task must be clear for the other team members and continuously stimulate and support the patients in participating actively in the program ${ }^{[4,5,9]}$.

According to local nutritional guidelines which were published in 2003 and based on the recommendations of the European Society of Parenteral and Enteral Nutrition (ESPEN) ${ }^{[10]}$ nurses are responsible for identifying patients at nutritional risk and involving staff with the right qualifications in planning interventions to achieve sufficient nutritional intake.

Nutritional care on FTPs requires nurses to involve and give patients precise information about managing a sufficient nutritional intake in order to prevent complications and to maintain their bodyweight during admission and after discharge ${ }^{[4]}$.

Nutritional care requires nurses with competencies and abilities to assess, decide, and manage patients' nutritional problems, as nutritional care may need to be performed at both general and advanced levels ${ }^{[11-14]}$. Furthermore, implementing FTPs necessitates a standardised nursing care regime, which focuses specifically on evidence-based goals related to nutrition ${ }^{[4,15]}$.

Nurses do regard nutritional assessment and care as part of their responsibilities ${ }^{[11]}$, and they do understand the importance of nutritional care on FTPs. The nutritional care can be improved by focusing on clinical nutrition by means of education, debates among colleagues, and by delivering health-promoting nutritional care ${ }^{[11]}$.

The present study is part of a larger project focusing on the impact of a training program for nurses with special responsibility for nutrition, i.e. Nutritional Nurse Practitioners (NNPs). In a previous study it was proven that the training program in general enhanced the NNPs' awareness of nutritional care and introduced a wider range of practices to manage it. The analysis revealed that the NNPs talked about elements related to FTPs, which was not analysed further at that time $^{[16]}$. It was also proven that implementation of the nutritional guideline improved the quality of care ${ }^{[17]}$.

\section{Aim}

The aim of this part of the study is to report to what extent a training program has made Nutritional Nurse Practitioners aware of the nutritional care for short-term hospitalized patients, and how they deal with patients' nutritional needs and ability to provide self-care in the context of a fast track program.

\section{Methods}

A secondary analysis was conducted to explore to what extent the NNPs are aware of the nutritional state of patients on fast track programs, their attitude to patients, and how they deal with patients' nutritional needs and ability to care for 
themselves. The focus group interviews ${ }^{[18-20]}$, which were carried out in January 2005 and March 2006 were re-analysed in order to highlight the points of views and opinions which emerged from the interactions and discussions between interviewees $^{[21]}$.

\subsection{Setting}

The study was carried out at the Heart Centre, Copenhagen University Hospital, Denmark. The Centre employs 285 registered nurses, has six wards comprising 169 beds with an average occupancy rate of $98 \%$ and a 6 days length of stay. The Centre performs heart and lung transplants and treats patients with acute medical heart disease such as myocardial infarctions, arrhythmias and endocarditis. Treatment includes classic thoracic surgery for congenital heart disease, coronary artery by-pass grafting (CABG), and valve disorders and surgical procedures for lung diseases, i.e. mostly patients with lung cancer.

\subsection{Participants}

16 registered nurses from a medical or a surgery ward, who in 2004 were appointed NNPs, were included as participants in the study. The NNPs were responsible for quality of nutritional care for the patients in the wards in which they were employed and for implementation of nutritional guidelines.

\subsection{Training program}

The nursing administration of the centre sat up a special training program designed for the NNPs and all 16 attended the program. The training program included five modules of three to four days' duration and was based on experimental learning theories ${ }^{[22,23]}$. The program combined nutritional aspects with issues of implementation and theories on planned change. The program included: basic academic skills, basic nutritional education (risk assessment, consequences of malnutrition, assessment of nutritional needs, responsibility), patient-specific factors related to malnutrition (eating difficulties, lack of knowledge, motivational theories and the food ordering system (meal choices, menus, choices of snacks)), implementation of changes in an organisation (the role of the leader, motivational theories, methods for identifying culture and attitudes in clinical settings) and literature search.

\subsection{Data collection}

There were held focus group interviews ${ }^{[18-20]}$ in order to use the interaction between the NNPs and thereby gather information on how they as a group understood and managed routine nutritional care, and to reveal information about their opinion of and experiences with nutrition assessment and management ${ }^{[24-26]}$.

One week before they attended the training programme the 16 NNPs were randomly divided into two groups and interviewed, this was done to establish a baseline for their attitude to nutritional management and how they understood their roles as NNPs.

The same two groups were interviewed one year later, after they had finished the training program, in order to identify possible changes. The two groups were interviewed in a quiet meeting-room at the hospital. Each focus group interview lasted two hours. All of the interviews were conducted by one of the investigators, $\mathrm{MB}$, an experienced researcher in conducting interviews and has research-related knowledge of nutrition. The interviewees were asked about their views about fulfilling their role as NNPs. The interviews was tape-recorded and transcribed verbatim (including non-verbal information) and checked for accuracy. All topics in the semi-structured interview guide (see Table 1) were discussed at each interview.

\subsection{I nterview guide}

Before and after the intervention the NNPs were asked eleven questions (see Table 1) in order to provide answers for the study's main questions: did the program improve the nurses' knowledge of nutrition and did it increase the nurses' awareness of their responsibility for nutritional care? 
Table 1. Interview guide

\begin{tabular}{l}
\hline 1) How do you consider nutrition as part of nurses' field of work, compared to other working tasks? \\
2) How would you describe nurses' responsibility for nutrition? \\
3) What is your opinion towards nursing responsibility for nutrition? \\
4) What do you expect from the training program? / Were your expectations fulfilled? \\
5) How do you manage nutrition in the day to day care? \\
6) What is good nutritional care? \\
7) What is the ideal procedure in relation to the individual patient? \\
8) What do you discuss with the patients about nutrition at their admission? \\
9) What are your possibilities to fulfill your responsibility for nutrition? \\
10) What are your possibilities when you identify a patient in risk of malnutrition / nutritional problem? \\
11) What are your possibilities in relation to nutritional practice?
\end{tabular}

\subsection{Analysis}

JG, who is a clinical nurse specialist and familiar with clinical nutrition conducted a secondary analysis of the transcribed interviews. The outline was discussed with two experienced researchers, MB, who had conducted the interviews and PUP, who are an experienced researcher in clinical nutrition. This was done in order to rule out misunderstandings and maximise rigour and validity ${ }^{[27,28]}$.

The transcribed focus group interviews were analysed according to qualitative deductive content analysis ${ }^{\text {[29-31] }}$.

The interviews were analysed using the model: "look - think - act" analysing and explaining the assumption, that the only way to promote lasting beneficial change in health care delivery is to actively involve staff ${ }^{[32]}$. So, it meets the aim to study the NNPs': ability to 'look', i.e. examine clinical matters related to nutrition and how they understand their role as NNPs; their capability to 'think', i.e. convert clinical topics into scientific problems that can be systematically studied, compared to existing scientific knowledge, and employed in clinical nutrition and their ability to 'act', i.e. base the decision-making about nutrition management on their observations.

The model was operationalized (see Table 2) into five categories:

1) The role of Nutritional Nurse Practitioner (NNP)

2) Understanding of clinical nutrition and fast track programs (FTPs)

3) Approach to clinical nutrition and patients admitted to fast track programs (FTPs)

4) Assessment and decision-making in clinical nutrition on fast track programs (FTPs) - at general and advanced levels

5) Expectations about nutritional care for patients admitted to fast track programs (FTPs)

The concepts in Table 2 demonstrate how these categories meet the study's aim and underlying assumptions, subsequently assuring the study's validity. Research questions were formulated for each category, according to which the interviews were coded systematically.

Themes that explained the assumptions embedded in the study's aim ${ }^{[29]}$ were derived from the coded meaning-units, which had been condensed and analysed.

\subsection{Ethical conciderations}

The Board of Directors at Copenhagen University Hospital, Denmark where the study was carried out approved the main research project. The NNPs attending the program were asked to contribute to the focus group interviews and were informed that the transcribed interviews were anonymous. 
Table 2. Nutritional Nurse Practitioners - From assumptions to research questions

\begin{tabular}{|c|c|c|c|c|c|}
\hline Assumptions & Aim & $\begin{array}{l}\text { Theoretical } \\
\text { frame }\end{array}$ & Categories & Concepts & Research questions \\
\hline \multirow[b]{2}{*}{$\begin{array}{l}\text { The training program has led } \\
\text { to increased competencies - } \\
\text { in both knowledge and skills } \\
\text { - in NNPs that will enhance } \\
\text { their awareness with regard } \\
\text { to: } \\
\text { - identification of nutritional } \\
\text { problems in patients } \\
\text { admitted to FTPs } \\
\text { - the importance of sharing } \\
\text { knowledge with both } \\
\text { colleagues and patients } \\
\text { admitted for FTPs. }\end{array}$} & \multirow{5}{*}{$\begin{array}{l}\text { To analyze if } \\
\text { the Nutritional } \\
\text { Nurse } \\
\text { Practitioners } \\
\text { (NNPs) use } \\
\text { nursing } \\
\text { competencies - } \\
\text { both knowledge } \\
\text { and skills - in } \\
\text { relation to } \\
\text { nutritional care } \\
\text { when } \\
\text { cooperating } \\
\text { with patients } \\
\text { admitted to fast } \\
\text { track programs } \\
\text { (FTPs) }\end{array}$} & & The role as NNP & $\begin{array}{l}\text { Role-model, resource-person } \\
\text { Teaching, advice, supervision } \\
\text { Nutrition as a core point } \\
\text { Monitor, follow up }\end{array}$ & $\begin{array}{l}\text { How do the NNPs talk about their } \\
\text { area of responsibility? How do } \\
\text { they describe it? } \\
\text { Who do they see as actors in their } \\
\text { area of responsibility? }\end{array}$ \\
\hline & & $\begin{array}{l}\text { Look } \\
\text { (Awareness) }\end{array}$ & $\begin{array}{l}\text { Understanding of } \\
\text { clinical nutrition } \\
\text { and FTPs }\end{array}$ & $\begin{array}{l}\text { Nutritional state and health } \\
\text { Nutrition as a core point of care } \\
\text { Def. of clinical nutrition } \\
\text { Identification of patient in } \\
\text { nutritional risk } \\
\text { Fast track programs and nutrition } \\
\text { Nurses' area of responsibility in } \\
\text { nutritional care }\end{array}$ & $\begin{array}{l}\text { How do the NNPs describe good } \\
\text { nutritional care? What kind of } \\
\text { knowledge do the NNPs talk about } \\
\text { as being important for nurses, } \\
\text { those who perform nutritional } \\
\text { care? } \\
\text { How do the NNPs describe } \\
\text { patients in particular need of } \\
\text { nutritional attention? } \\
\text { How do the NNPs talk about being } \\
\text { responsible for the nutritional care } \\
\text { for the patient admitted for FTPs, } \\
\text { both during the hospital stay and } \\
\text { after discharge? }\end{array}$ \\
\hline $\begin{array}{l}\text { The training program has } \\
\text { increased the awareness of } \\
\text { the responsibility for } \\
\text { health-promoting nutritional } \\
\text { care in NNPs and has had a } \\
\text { positive influence on the } \\
\text { NNPs' attitudes toward the } \\
\text { nutritional problems of } \\
\text { patients admitted to FTPs - } \\
\text { seen from both the } \\
\text { perspective of the patient } \\
\text { and the society. }\end{array}$ & & $\begin{array}{l}\text { Think } \\
\text { (Attitude) }\end{array}$ & $\begin{array}{l}\text { Approach to } \\
\text { clinical nutrition } \\
\text { and patients } \\
\text { admitted to FTPs }\end{array}$ & $\begin{array}{l}\text { Nutritional state and health } \\
\text { assessment related to nutritional } \\
\text { requirements and intake } \\
\text { Aspect of nutritional care } \\
\text { Cooperation - patient, relatives } \\
\text { and health professionals } \\
\text { Patient as partner - also after } \\
\text { discharge } \\
\text { Targets - in short and long term }\end{array}$ & $\begin{array}{l}\text { How do the NNPs talk about the } \\
\text { importance of nutritional care in } \\
\text { conjunction with other care issues } \\
\text { of the patient? } \\
\text { How do the NNPs describe the } \\
\text { ideal nutritional care to the } \\
\text { individual patient? And the ideal } \\
\text { nutritional care to the patient } \\
\text { admitted for FTP? } \\
\text { How do the NNPs talk about } \\
\text { cooperation with and education of } \\
\text { the patient, the relatives and health } \\
\text { professionals, who are involved in } \\
\text { the patient's need for nutritional } \\
\text { care? }\end{array}$ \\
\hline $\begin{array}{l}\text { The training program has led } \\
\text { to increased competencies - } \\
\text { in both knowledge and skills } \\
\text { - in NNPs and will enhance } \\
\text { their' abilities to assess, } \\
\text { decide and manage the } \\
\text { nutritional problems of the } \\
\text { patients admitted to FTPs. } \\
\text { Nutritional care will be } \\
\text { performed on both a general } \\
\text { and an advanced level } \\
\text { related to the needs of the } \\
\text { patient. For patients on FTPs } \\
\text { there will be plans in } \\
\text { advance. }\end{array}$ & & \multirow{2}{*}{$\begin{array}{l}\text { Act } \\
\text { (Management) }\end{array}$} & $\begin{array}{l}\text { Management of } \\
\text { assessment and } \\
\text { decision-making } \\
\text { in clinical nutrition } \\
\text { related to patients } \\
\text { admitted to FTPs, } \\
\text { at on both general } \\
\text { and advanced level }\end{array}$ & $\begin{array}{l}\text { Assessment related to nutritional } \\
\text { requirements and intake. } \\
\text { Cooperation; patient, relatives and } \\
\text { health professionals. } \\
\text { Patient as partner, also after } \\
\text { discharge. } \\
\text { Targets - in the short and long } \\
\text { term - also after discharge. } \\
\text { Plan and perform nutritional care. }\end{array}$ & $\begin{array}{l}\text { What do the NNPs say about } \\
\text { management of nutritional care on } \\
\text { daily basis? } \\
\text { What do the NNPs say about } \\
\text { planning, performing and } \\
\text { evaluating nursing performance? } \\
\text { How do the NNPs describe } \\
\text { cooperation with the patient? What } \\
\text { do the NNPs mention as topics } \\
\text { when they teach, advise and } \\
\text { supervise the patient? } \\
\text { How do the NNPs talk about } \\
\text { preparing the patient for discharge } \\
\text { from hospital? }\end{array}$ \\
\hline $\begin{array}{l}\text { The training program has } \\
\text { given the NNPs an insight } \\
\text { into the research process } \\
\text { which will enhance their } \\
\text { awareness of the resources } \\
\text { of the patient admitted to a } \\
\text { FTP. Which are the } \\
\text { predisposing, the enabling } \\
\text { and the reinforcing factors of } \\
\text { the patient that makes it } \\
\text { possible for the patients } \\
\text { admitted for FTPs to master } \\
\text { self care related to } \\
\text { nutritional problems in the } \\
\text { time post-discharge? }\end{array}$ & & & $\begin{array}{l}\text { Expectations } \\
\text { toward nutritional } \\
\text { care related to } \\
\text { patients admitted } \\
\text { for FTPs. }\end{array}$ & $\begin{array}{l}\text { Objectives and areas for } \\
\text { exploration related to the patient's } \\
\text { knowledge about healthy nutrition } \\
\text { after surgery. } \\
\text { Implementation of knowledge } \\
\text { about clinical nutrition and } \\
\text { patients admitted to fast track } \\
\text { programs }\end{array}$ & $\begin{array}{l}\text { How do the NNPs describe the } \\
\text { challenges of nutritional care } \\
\text { related to patients admitted for } \\
\text { FTPs? }\end{array}$ \\
\hline
\end{tabular}




\section{Results}

\subsection{The role of Nutritional Nurse Practitioner (NNP)}

The NNPs have a positive attitude towards their role. "I think there are some exciting tasks... I think it's good that we are in charge of nutrition...” They refer to patients, other nurses, and physicians as co-players in their area of responsibility for nutrition. They are aware of their responsibility for the patients' nutritional state, and for their nutritional care. “...we know that the physicians are responsible for clinical nutrition... but it is mostly us who prescribe [nutritional care] unless it comes to intravenous alimentation and fluids.”

They refer to their position as "resource people" who teach, advice, and supervise the other nurses, as well as supporting their management of specific nutritional problems. "If they come and ask for advice... 'I'll help you or we'll find out together...' it is never about ...'No, I have no time'. I'd never dream of saying that ... I feel very responsible.”

Fulfilling their roles, as NNPs requires specific competencies in order to be role models and resource people for the other nurses in the ward, and also to monitor and develop the quality of the nutritional care given to patients. The NNPs regularly monitor the quality of nutritional care through audits, using the indicators of structure and process based on the nutritional guidelines.

\subsection{Understanding of clinical nutrition and fast track programs (FTPs)}

NNPs know that insufficient nutrition has deleterious effects on the patient's rehabilitation. Providing information and guidance to the patients and their relatives is essential before discharge, because it is difficult for the patients and their relatives to access nutritional advice outside the hospital, especially when patients are not in contact with health services. Nutritional care also includes arranging an appetising dining environment and alternating between offering help, guidance, information, and encouraging the short-term hospitalised, “...because they have a few days to learn it, understand me correctly, learn, and get started ... they need to eat and motivate themselves to get started...”Time constraints do sometimes induce an inattentive attitude to patients with nutritional problems. Standards for nutritional care for patients on FTPs appear to be defined in broad terms, as NNPs do not focus on the information this particular group of patients' needs. Instead, they confine their advice to expressing concerns about the patients, “...if he's in hospital in the short-term and ... if he doesn't like the food and we aren't aware of it because of our workload ... then you can easily overlook the patient definitely!"NNPs believe that good nutritional care ought to be planned with the patient, with the intention of informing them, and inviting them to be a partner in reaching their nutritional care goals. "The patient must be consulted ... for him to know that his opinion is being listened to, that can be really motivating too."

The goals of nutritional care must be realistic for the patient and the interventions should be documented accurately in the care plans to ensure continuity. Patients need information about the composition of their food and the consequences of not eating, "...then the patient is in a better position, to be... first of all, involved, but also able to take responsibility."

When the patients are in contact with health services, or are admitted to another hospital after discharge, the nurses are confident because they can pass their concerns about the patients' nutritional state to the nurse who takes over.

The NNPs are concerned with short-term hospitalised patients, patients with eating difficulties, and patients with nausea, which can cause severe nutritional problems and complications like infections. It is also a concern that patients do not know enough about nutrition related to recovery, and that they may find it difficult to find this information after discharge,

"...patients must have a lot of insight, be educated, or be smart to go to the Heart Foundation for guidance or go to a dietician...” 


\subsection{Approaches to clinical nutrition and patients admitted for fast track programs (FTPs)}

The NNPs agree that clinical nutrition is as important to the patients as any other kind of treatment during hospitalization. Most patients need to know how to make the right choices from the hospital menu, because they do not know how their illness will affect their nutritional intake. "They [the patients] all look very surprised, when you walk in and tell them about what is physically happening.”

NNPs are also aware that proper food may be something very different from the patients' perspective, “...they have different perceptions, have been cooking in different ways, or eat every now and again, or are still cooking as they did in the post-war period.”

It is difficult for nurses to remain focused on nutritional care, which is perceived to be somewhat universal. Medical treatment, ward rounds and related nursing tasks are given higher priority because, as opposed to nutritional care, they show immediate results.

The nutritional guidelines focus on patients who are screened as being at nutritional risk. NNPs mentioned that patients who are found to be potentially at risk of malnutrition might need preventive nutritional care. This is not the NNPs' own focus, but, in their opinion, it ought to be clinically developed, “... it is about the way the scheme has been implemented... much focus on those patients who are at nutritional risk, but not so much focus on prevention, which the scheme also provides for overleaf...”

\subsection{Assessment and decision-making in clinical nutrition on fast track programs (FTPs) - at general and advanced levels}

The NNPs do not mention the patients admitted for FTPs when talking about assessment and decision-making in clinical nutrition. They do, however, speak about the importance of the patient being in good nutritional shape before surgery, and that they want to improve their management of that point. "When the patient goes home and has to return to undergo surgery, even then, we try to be better at informing the patient about dietary intake in the meantime, to be best prepared ... for surgery."

During the patient's hospitalisation nurses try to cooperate with and involve the patient and the relatives. They inform and advise both parts about proper nutrition for the patient, and expect the patient to cooperate in order to meet their nutritional care goals, “...we would prefer that the patient says ... now it's time for my snack...”

The sizeable workload of planning, performing and evaluating nutritional care, which the nurses must take care of on a daily basis, is considered a problem. Even though most nurses know how nutritional care ought to be carried out, and most patients' nutritional state is assessed according to the clinical guidelines, they give it lower priority when other tasks sometimes interrupt them "...because suddenly there is a physician, who is waiting for ward rounds..."

When NNPs talk about preparing the patient for discharge, they state that nutritional problems should be documented by the physician to inform general practitioners, or documented by the nurses to inform health services. The staff at health services can then be aware of the nutritional state of the patient. Concerning patients, who do not receive help from health services; it is important that they and their relatives are well-informed about what to do if their body weight is decreasing. The NNPs would like to develop some new material - something more visual and individual - to help the patient to focus on long term goals, i.e. nutrition after discharge. "Something individual ... maybe something in writing, but also visual, to show them [the patients] what they could eat in a day.” 


\subsection{Expectations of nutritional care for patients admitted for fast track programs (FTPs)}

NNPs discuss the challenges relating to fast track nutritional care programs, without mentioning the concept 'fast track', even though the patients they speak of will soon be discharged. As such, the patients have only a short time to learn to take care of themselves. NNPs know that nutrition is an important topic, but nevertheless find it awkward to speak to patients about it when they are hospitalised for only two or three days. They recognise this problem, “...we try to do better to inform patients about their dietary intake while they're waiting for surgery...”

NNPs express doubts when they speak about patients' predisposing factors and ability to take care of themselves after discharge. They see it as unrealistic to expect middle-aged patients to change their dietary habits in a hospitalisation period of six to seven days. They are aware that, patients should be informed and counselled about their diet, and supported with techniques to deal with nutritional problems after discharge. NNPs are also aware that from the patient's perspective, this information is important, “...they want to be informed about what’s good for them [to eat].”

Seemingly the NNPs are afraid to leave responsibility for nutrition in the hands of the patients themselves. They are more comfortable when the patients are transferred to be cared for by a colleague in the healthcare system. "It [nutrition] can be a problem, especially after discharge, because nobody takes over afterwards... while they [the patients] are in hospital, you're sometimes anxious about whether it's going to work well when they come home ... even though you've told them what they should eat.”

\section{Discussion}

The two main findings of the present study are that being a NNP involves responsibility for nutrition in a broader sense, and that patients admitted to FTPs, with their special need for nutritional care, are almost invisible to the NNPs. On the one hand, the results indicate that NNPs are aware of nurse-specific actions and that nutritional care is just as important as any other treatment during hospitalisation. On the other hand, the results also show that they are under the impression that their substantial workload is an obstacle to fulfilling proper nutritional care. From the transversal analysis of the results two explanatory themes emerged $\left.{ }^{[29]}: 1\right)$ the invisible nutritional needs of the invisible patients make the nursing profession invisible and 2) perceived time constraints limit the management and development of nutritional care.

Linking these two themes, a paradox evolves. Firstly, if patients at nutritional risk are not identified, there will be no need for nurses responsible for nutrition, no need for their nutritional care management competencies, and no awareness of the importance of nutritional health promotion. Secondly, how can time constraints put a limit on the management and development of nutritional care if nutritional care is given low priority? It might be said too, that if the nursing profession does not focus on nutrition, there is no need for NNPs.

It is well-known that appropriate nutrition is vital for the patient's recovery ${ }^{[13,33]}$, and that undernourished inpatients are still reported ${ }^{[34-36]}$. As nurses are responsible for nutritional care to patients at nutritional risk they ought to respond to this knowledge ${ }^{[10,11,37]}$. This gives rise to the question of whether nurses really want to be responsible for nutrition. The original study proved that the training program enhanced NNPs' awareness of nutritional care and introduced a wider range of methods of managing nutritional care ${ }^{[16]}$. It also showed that the strategy on which the training program was based facilitated the implementation of nutritional guidelines ${ }^{[17]}$. This part of the study reveals that NNPs are aware of nurse-specific actions, and aware that nutritional care is just as important as any other treatment during hospitalisation. However, when it comes to managing daily nutritional care, nurses do not give nutrition priority, if they deem another task to have greater importance. Additionally, if NNPs do not prioritise their specialism, nor will their fellow nurses. This gives rise to another question; how do nurses wish to present themselves to their collaborators in the healthcare system? As the assistant of the physician? As generalists with a well-developed knowledge of specialist areas of nursing care, such as 
nutrition or cardiology? If nurses want to seize the opportunity to actively prescribe nursing care to the patient, many changes will have to be made at all levels in nursing education and organisation.

\subsection{The invisible nutritional needs of the invisible patients make the nursing profession invisible}

NNPs' apparent attitude is that nutritional care is just as important as any other treatment, and that knowledge of clinical nutrition is essential in understanding the importance of nutrition for the patient's recovery.

FTPs were introduced in Denmark in the $1990 \mathrm{~s}^{[4]}$ and subsequently recommended to all groups of patients ${ }^{[1]}$. It could therefore be presumed that NNPs would be mindful of the purpose behind the concept, and use it in handling problems related to short-term hospitalised patients. Information about nutrition is important to patients admitted to FTPs, because it is related to the success of the treatment and enables the patients to take care of themselves after discharge ${ }^{[5-7]}$. Then it is thought provoking that NNPs do not speak about their approach to clinical nutrition for fast track patients. Patients who are admitted for a few days are physically present in the ward, but there does not seem to be a standard for their nutritional care. NNPs explain how short-term hospitalised patients can easily be overlooked when it comes to potential or existing nutritional problems. These patients vanish within the group that follows programs in the hospital, as they are discharged after a few days. In reality a study proved that nurses did improve patients' knowledge of nutrition, identified eating disorders and increased the intake of snacks between meals ${ }^{[17]}$. Therefore it seems inconsistent that NNPs on the one hand describe how little the patients know about nutrition, while they are not able to describe what they actually do in every day clinical practice. When nurses cannot describe clearly what they do, the consequence could be that the contribution of the nursing profession becomes invisible to the patient, the relatives, and the healthcare system. So, efforts are required on the part of nurses to be able to clarify the role of nursing if they want to play an active role in the multidisciplinary team and collaborate with patients and relatives.

The importance of everyday nutritional care also seems to be invisible to nurses. It appears to be difficult for nurses to focus on nutritional care, which might be due to the fact that nutritional care does not have immediate results for the patient. Instead, nurses give a higher priority to tasks delegated by the physician, which are deemed to be of more vital character. It is of great importance to treat the patient's condition, and sometimes every minute counts, but nutrition is also absolutely essential in supporting the patient's recovery. According to Stratton et al., sufficient nutrition decreases the risk of complications, diminishes mortality levels, lowers the costs of hospitalisation, and improves the patient's quality of life ${ }^{[13]}$. In light of this, nurses should take advantage of the opportunity to engage in nutritional care, which is within their area of responsibility ${ }^{[12,16]}$, in a process where care and treatment work together to achieve the best outcome for patients. One way to implement this might be to encourage head nurses to bring nutritional care into focus when newly hired nurses are introduced to their work in the ward. To maintain good standards for nutritional care requires that it is asked for and defined by nurses at the management level ${ }^{[38]}$.

In order to improve nutritional intake it is important to identify existing and potential nutritional problems, and to plan nutritional treatment and nutritional care accordingly ${ }^{[13]}$. The successful implementation of fast track programs requires health professionals and patients to cooperate, and necessitates that both standards for treatment and care are known and understood by everybody involved. As nutrition is considered a cornerstone of fast track programs ${ }^{[4]}$, it is important that nurses are able to think, in the patients' clinical pathways, how nutritional needs can change both during and after admission ${ }^{[10]}$, and to promote health, while taking the patient's way of thinking in account ${ }^{[8]}$.

More and more treatments are planned as FTPs, so, the health care system demands nursing competencies to identify, assess, plan and care for patients who are, or who may be, at nutritional risk. Patients are expected to cooperate, and adhere to the program in order to achieve a positive outcome. Collaboration requires that patients are informed, understand course of treatment, and know what is expected of them. It also requires that patients trust and have confidence in their collaborators, but NNPs' trust and confidence in their patients` ability to manage life after discharge is invisible. They 
express doubts related to the patient's predisposing, enabling and reinforcing factors ${ }^{[9]}$ and thereby the patients' ability to handle their nutritional problems after discharge. NNPs feel more confident when the patient is cared for by a health care professional elsewhere in the health care system. Such an attitude contradicts the purpose of fast track programs and the aims of shared responsibility and self-care. For nurses, this might represent a deliberate and conspicuous strategy, which would entail their visibility as nurses.

\subsection{Perceived time constraints limit the management and development of nutritional care}

It would appear that time constraints related to workload are a problem for nurses in managing daily nutritional care, causing them to pay less attention to patients with nutritional problems. Nurses know how nutritional care ought to be carried out ${ }^{[10]}$, but other tasks are often given higher priority. Acute and critical situations in nursing can cause nurses to give tasks delegated by the physician higher priority, and put nutritional care temporarily aside. However, when acute and critical situations have passed, nursing care and nutritional care should be given priority. Since sufficient nutrition is important for the patient's recovery ${ }^{[11,37]}$ and responsibility for nutritional care belongs to the nursing profession ${ }^{[10]}$, it is urgent that nurses demonstrate their authority in the area of nutrition, and that they give priority to the management, assessment, planning, performance, and evaluation of nutritional care. The assessment of patients' nutritional condition solely by the guidelines is insufficient ${ }^{[10]}$. Assessments have to be followed up by plans, interventions and reassessments if the patient is in actual or potential need of nutritional care. Equally important is the monitoring and evaluation of the fast track patient's nutritional state ${ }^{[39]}$.

NNPs would like to develop clinical nutrition within the nursing profession, but state that various time constraints prevent such an effort; for instance, their fellow-nurses expect them to care for their fair share of the patients. However, allocating designated hours to NNPs may contribute to improving nutritional care. In these hours, NNPs must be supervised by an experienced researcher, which would be in line with other trends in the healthcare system. Both the patients and the health care system will probably benefit from these efforts, as the patient's rehabilitation is strengthened and the costs of providing health care reduced ${ }^{[1]}$.

\section{Conclusion}

Previously it has been proven, that attending a training program, provided NNPs with knowledge and skills to care for patients at nutritional risk ${ }^{[16]}$. NNPs agree nutritional care is equally important as any other treatment during hospitalization. Nevertheless NNPs do not focus specifically on patients admitted for short-term, though they are concerned about these patients and how little they know about how their illness will affect their nutritional intake. Time constrains and workload is mentioned as reasons for being unable to fulfil proper nutritional care. Another explanation might be the priority nutritional care is given. As nutritional care does not show immediate effect, the nurses give nutritional care low priority when other tasks interrupt them, and as the patients are discharged within few days, their possible nutritional needs are not recognised.

The NNPs express doubts when they speak about patients' predisposing factors and ability to take care of themselves after short-term hospitalization. NNPs find it unrealistic to expect middle-aged patients to change their dietary habits after being admitted for a few days and are worried to leave responsibility for nutrition in the hands of these patients. NNPs are more comfortable when the patients are transferred to be cared for by a colleague in the healthcare system.

\section{References}

[1] Wilmore DW, Kehlet H. Clinical Review. Managesment of patients in fast-track surgery. British Medical Journal. 2001; 322(7284): 473-6. http://dx.doi.org/10.1136/bmj.322.7284.473 
[2] Basse L, Jakobsen DH, Bardram L, Billesbølle P, Lund C, Mogensen T, et al. Functional Recovery After Open Versus Laparascopic Colonic Resection. A Randomized, Blinded Study. Annals of Surgery. 2005 March; 241(3): 416-423. PMid:15729063 http://dx.doi.org/10.1097/01.sla.0000154149.85506.36

[3] Wang D, Kong Y, Zhong B, Zhou X, Zhou Y. Fast-track Surgery Improves Postoperative Recovery in Patients with Gastric Canser: A Randomized Comparison with Conventional Postoperative Care. Journal of Gastrointest Surgery. 2010; 14 : $620-627$. PMid:20108171 http://dx.doi.org/10.1007/s11605-009-1139-5

[4] Norlyk A. After colonic surgery.A phenomenological study of participating in a fast-track programme. PhD thesis. Faculty of Health Sciences, Aarhus University. 2009.

[5] Baird G, Maxson P, Wrobleski D, Luna B. Fast-track Colorectal Surgery Program reduces Hospital Length of Stay. Clinical Nurse Specialist. 2010; 24(4): 202-208. PMid:20526121 http://dx.doi.org/10.1097/NUR.0b013e3181e3604c

[6] Kehlet H, Wilmore DW. Evidence-Based Surgical Care and the Evolution of Fast-Track Surgery. Annals of Surgery. 2008; 248(2): 189-198. PMid:18650627 http://dx.doi.org/10.1097/SLA.0b013e31817f2c1a

[7] Kehlet H. Multimodal approach to postoperative recovery. Current Opinion in Critical Care. 2009; 15: 355-358. PMid:19617822 http://dx.doi.org/10.1097/MCC.0b013e32832fbbe7

[8] Nieuwenhuizen WF, Weenen H, Rigby P, Hetherington MM. Older adults andpatients in need of nutritional support: Review of current treatment options and factors influencing nutritional intake. Clinical Nutrition. 2010; 29: 160-169. PMid:19828215 http://dx.doi.org/10.1016/j.clnu.2009.09.003

[9] Green LW, Kreuter MW. Health Promoting Today and a framework for Planning. In: Health promotion planning - An educational and environmental approach. 2nd. ed. Mountain View: Mayfield Publishing Company.1991.

[10] Kondrup J, Højgaard Rasmussen H, Hamberg O, Stanga Z. Nutritional risk screening (NRS 2002): a new method based on an analysis of controlled clinical trials. Clinical Nutrition. 2003; 22(3): 321-36. http://dx.doi.org/10.1016/S0261-5614(02)00214-5

[11] Perry L. Nutrition: a hard nut to crack. An exploration of the knowledge, attitudes and activities of qualified nurses in relation to nutritional nursing care. Journal of Clinical Nursing. 1997; 6(4): 315-24. http://dx.doi.org/10.1111/j.1365-2702.1997.tb00320.x

[12] Rasmussen HH, Kondrup J, Ladefoged K, Staun M. Clinical nutrition in Danish hospitals: a questionnaire-based investigation among doctors and nurses. Clinical Nutrition. 1999; 18(3): 153-8. http://dx.doi.org/10.1016/S0261-5614(99)80005-3

[13] Stratton RJ, Green CJ, Elia M. Disease-related malnutrition - an evidence-based approached to treatment. Cambridge: CABI Publishing. 2002.

[14] Mowe M, Bosaeus I, Rasmussen HH, Kondrup J, Unosson M, Rothenberg E. Insufficient nutritional knowledge among health care workers? Clinical Nutrition. 2008; 27(2): 196-202. PMid:18295936 http://dx.doi.org/10.1016/j.clnu.2007.10.014

[15] Egerod I, Rud K, Jensen PS. En pakkeløsning til patienterne - accellerede operationsforløb og kliniske vejledninger. Sygeplejersken. 2006; nr. 17.

[16] Bjerrum M, Tewes M, Pedersen P. Nurses' self-reported knowledge about and attitude to nutrition - before and after a training programme. Scandinavian Journal of Caring Sciences. 2012; 26(1): 1-2. PMid:21718341 http://dx.doi.org/10.1111/j.1471-6712.2011.00906.x

[17] Pedersen PU, Tewes M, Bjerrum M. Implementing a nutritional guideline - the effect of systematic training nurses. Scandinavian Journal of Caring Sciences. 2012; 26(1): 1-2. PMid:21883340 http://dx.doi.org/10.1111/j.1471-6712.2011.00912.x

[18] Wibeck V. Fokusgrupper. Om fokuserade gruppeintervjuer som undersökningsmetod. Lund: Studenterlitteratur. 2000.

[19] Flick U. An Introduction to Qualitative Research. 2 ed. London: SAGE Publications. 2005.

[20] Redmond R, Curtis E. Focus groups: principles and process. Nurse Researcher. 2009; 16(3): 57-69. PMid:19425401 http://dx.doi.org/10.7748/nr2009.04.16.3.57.c6946

[21] Kvale S. Om tolkning af kvalitative forskningsinterview. Tidsskrift för Nordisk Förening för Pedagogisk Forskning. 1984; 4(3,4): 55-66.

[22] Marcus MT, Walker T, Swint JM, Smith BP, Brown C, Busen N. Community-based paticipatory research to prevent substance abuse and HIV/AIDS in African-American adolescents. Journal of Interprofessional Care. 2004; 18(4): 347-59. PMid:15801550 http://dx.doi.org/10.1080/13561820400011776

[23] Kolb AY, Kolb DA. Learning styles and learning spaces: Enhancing experiential learning in higher education. Academy of Management Learning \& Education. 2005; 4(2): 193-212. http://dx.doi.org/10.5465/AMLE.2005.17268566

[24] Trenkner LL, Achterberg CL. Use of focus groups in evaluating nutrition education materials. Journal of the Amarican Dietetic Association. 1991; 91(12): 1577-81. PMid:1960352

[25] Webb C, Kevern J. Focus groups as a research method: a critique of some aspects of their use in nursing research. Journal of Advanced Nursing. 2001; 33(6): 798-805. http://dx.doi.org/10.1046/j.1365-2648.2001.01720.x

[26] Kälvemark S, Höglund AT, Hansson MG, Westerholm P, Arnetz B. Living with conflicts-ethical dilemmas and moral distress in the health care system. Social Science \& Medicine. 2004; 58(6): 1075-84. http://dx.doi.org/10.1016/S0277-9536(03)00279-X 
[27] Beyea SC, Nicoll LH. Collecting, analyzing, and interpreting focus group data. Association of Operating Room Nurses AORN Journal. 2000; Jun; 71(6): 1278-83. http://dx.doi.org/10.1016/S0001-2092(06)61446-4

[28] Kondracki NL, Wellman NS, Amundson DR. Content Analysis: Review of Methods and Their Applications in Nutrition Education. Journal of Nutrition Education and Behavior. 2007; 34(4): 224-30. http://dx.doi.org/10.1016/S1499-4046(06)60097-3

[29] Dey I. Qualitative Data Analysis. A user-Friendly Guide for Social Scientists.1 ed. London: Routledge. 2002.

[30] Neuendorf KA. Content Analysis Guidebook. London: Sage Publication. 2002.

[31] Krippendorff K. Content Analysis. An Introduction to Its Methodology. 2 ed. London: Sage Publications. 2004.

[32] Averill JB. Studies of Rural Elderly Individuals: Merging Critical Ethnography with Community-Based Action Research. Journal of Gerontological Nursing. 2005; 31(12): 11-18. PMid:16375093

[33] Heersink JT, Brown CJ, Dimaria-Ghalili RA, Locher J. Undernutrition in Hospitalized Older Adults: Patterns and Correlates, Outcomes, and Oppertunities for Intervention with a Focus on Processes of Care. Journal of Nutrition for Elderly. 2010; 29(1): 4-41. PMid:20391041 http://dx.doi.org/10.1080/01639360903574585

[34] Rasmussen HH, Kondrup J, Staun M, Ladefoged K, Kristensen H, Wengler A. Prevalence of patients at nutritional risk in Danish hospitals. Clinical Nutrition. 2004; 23(5): 1009-15. PMid:15380890 http://dx.doi.org/10.1016/j.clnu.2004.01.001

[35] Lassen KØ, Kruse F, Bjerrum M. Nutritional care of Danish medical inpatients - patients' perspectives. Scandinavian Journal of Caring Science. 2005; 19(3): 259-67. PMid:16101854 http://dx.doi.org/10.1111/j.1471-6712.2005.00337.x

[36] Kubrak C, Jensen L. Malnutrition in acute care patients: A narrative review. International Journal of Nursing Studies. 2007; 44(6): 1036-54. PMid:16996065 http://dx.doi.org/10.1016/j.ijnurstu.2006.07.015

[37] Wentzel Persenius M, Larsson BW, Hall-Lord ML. Enteral nutrition in intensive care: Nurses' perceptions and bedside observations. Intensive and Critical Care Nursing. 2006; Apr; 22(2): 82-94. PMid:16289849 http://dx.doi.org/10.1016/j.iccn.2005.09.001

[38] Wærriø G. Sykepleiefaglig ledelse - noen utfordringer. Klinisk sygepleje. 2005; 3. Munksgaard, Danmark.

[39] Pedersen PU, Cameron U. Ældre ortopædkirurgiske patienters viden om kost, ønsker til måltidsrutiner og aktiviteter, der øger kostindtagelsen under sygehusindlæggelse. Vård i Norden. 1999; 19(1): 23-28. 